\title{
Estimation of Management Effectiveness of Electricity Supply Enterprises in Emerging Economies
}

\author{
Skibina Tetiana ${ }^{1}$, Kurbatova Tetiana ${ }^{2}$, Sotnyk Iryna ${ }^{3}$, \\ Telizhenko Oleksandr $^{4}$, Sotnyk Mykola ${ }^{5}$, Hyrchenko Yevgeniy ${ }^{6}$ \\ ${ }^{I}$ Finance and Credit Department, Kherson Economy and Law Institute, 130, Crimean Street, \\ UA-73009, Kherson, Ukraine \\ ${ }^{2}$ International Economic Relations Department, Sumy State University, 2, Rimsky-Korsakov Street, \\ UA-40007, Sumy, Ukraine \\ ${ }^{3}$ Department of Economics, Entrepreneurship and Business Administration, Sumy State University, 2, \\ Rimsky-Korsakov Street, UA-40007, Sumy, Ukraine \\ ${ }^{4}$ 138/2, General Karbyshev Street, UA-40017, Sumy, Ukraine \\ ${ }^{5}$ Department of Applied Hydro and Aeromechanics, Sumy State University, 2, Rimsky-Korsakov Street, \\ UA-40007, Sumy, Ukraine \\ ${ }^{6}$ International Economic Relations Department, Sumy State University, 2 , Rimsky-Korsakov Street, \\ UA-40007, Sumy, Ukraine
}

\begin{abstract}
The article gives an estimation of the management effectiveness of electricity supply enterprises in emerging economies on the example of enterprises of the northern and central regions of Ukraine. Estimation was conducted on the basis of the authors' methodological approach that applies the number of indicators taken as a basis for the formation of the integrated indicator. The latter allows carrying out a comprehensive estimation of the management effectiveness system of the electricity supply enterprises.
\end{abstract}

The obtained results show a low management effectiveness of the considered electricity supply enterprises. As a result, the conducted research

DOI: $10.18421 /$ TEM101-30

https://doi.org/10.18421/TEM101-30

Corresponding author: Kurbatova Tetiana,

PhD in Economics, Senior Lecturer of International Economic Relations Department, Sumy State University, 2, Rimsky-Korsakov Street, UA-40007, Sumy, Ukraine.

Email: t.kurbatova@macro.sumdu.edu.ua

Received: 18 August 2020.

Revised: 08 January 2021.

Accepted: 14 January 2021.

Published: 27 February 2021.

(cc) BY-NC-ND (C) 2021 Skibina Tetiana et al; published by UIKTEN. This work is licensed under the Creative Commons Attribution-NonCommercial-NoDerivs 4.0 License.

The article is published with Open Access at www.temjournal.com identified the barriers that hinder the efficient development of electricity supply enterprises and outlined the main directions for reforming energy supply enterprises' activity.

Keywords - management, effectiveness, electricity supply enterprise, emerging economy, Ukraine.

\section{Introduction}

Sustainable energy development of the countries is the key to the stability of national economies. Problems with its provision arise in the developed countries and in emerging economies. However, the latter group of states, perhaps, is the most vulnerable in terms of providing energy development without shocks. Considering the former Soviet republics, many of them inherited developed but outdated and energy intensive energy sectors and suffer from the economic and environmental inefficiency of domestic energy supply enterprises [1]. This results in high prices of energy and utilities, the increase in the number of emergencies in energy networks, nonproductive energy losses, rising greenhouse gas emissions. The lack of sufficient investments to the renewal of energy infrastructure and energy production technologies causes a gradual steady increase in the cost price of energy and energy services without improving the quality and reliability of energy supply [1]. As one of the prime examples of emerging economies, Ukraine has a developed energy industry, which significantly affects its economic stability and the population well-being. Currently, the power sector of Ukraine requires 
urgent reformation [2], as the old methods of electricity supply enterprises (ESE) management have failed to provide companies' adaptation to innovative changes, and thereby form conditions for adequate response to the electricity demand.

Together with electricity generation issues, caused by the lack of own fossil fuels, dependence on their import, negative influence of conventional energy on the environment, etc., there are many other problems in the electric power sector. They are connected with the of ESE activity and include the followings:

- poor technical state of electrical grids, which causes considerable electricity losses during its transmission and negatively affects the quality of electricity supply services. In addition, it prevents the electricity system from rapid adjustment to adding a significant amount of "green" electricity and the development of distributed generation;

- debt of the population for consumed electricity, which worsen the financial conditions of ESE [3];

- lack of the enterprises' working capital that makes it impossible to solve their current problems; imperfection of electricity metering system, which adversely affects the quality of the services provided [4], etc.

The mentioned issues cause crisis in electric power supply, overcoming of which is possible due to the improvement of management effectiveness (ME) of ESE by introducing modern approaches to crisis management that will substantially change management system.

An important tool for a quick identification of internal possibilities and current external threats to an enterprise is the estimation of its ME [5]. The results of the estimation allow revealing weaknesses and are the starting point for decision-making towards the improvement of the efficiency of enterprises' business activity [6].

In view of the above, it is relevant to improve the existing and develop new approaches to the estimation of the energy enterprises' ME in emerging economies on the example of Ukraine. Thus, the objectives of the research are: (1) the development of a methodological approach to an integrated assessment of the ME of ESE; (2) testing of the suggested approach on the example of ESE in the northern and central regions of Ukraine and (3) providing recommendations on the improvement of business entitites' management system on the basis of the estimation results. The main contribution of the paper is that the authors have suggested a new instrument for the assessment of ME of ESE in emerging economies and provided the policy recommendations for its implementation based on the ESE data from the north and center of Ukraine.

The rest of the paper is organized as follows. The Literature Review presents recent research findings on the essence of ME and models for its estimation at microlevel. The Methods and Methodology section reveals the information on the research methodological approach and its methods. Results and Discussion provides the testing results of the suggested approach on the example of ESE of the northern and central regions of Ukraine as well as discusses the problems and ways of increasing the ME of the business entities. Conclusions section presents policy recommendations regarding the results obtained.

\section{Literature Review}

The modern scientific literature presents a variety of theoretical and methodological approaches to understanding the term "ME". Some scientists consider ME as a level of purposes achievement, the established strategy, rate and stages of functioning and development of social and economic, production, organizational or technical component of an enterprise (see, for example [7], [8]). Other researchers understand $\mathrm{ME}$ as equivalent and interrelated concepts like "workforce productivity", "quality", "stability ", etc. (see, for example [9], [10]). The main difference of the existing methodological approaches to assessing the $\mathrm{ME}$ is in the very determining the essence of the management and economic category of ME. The most common definition of ME is the ratio of the obtained result to the costs, i.e. the ability of an organization to maximize profit at the reasonable costs it incurs.

Scientific discussions about the treatment of this term arise precisely because of its originality. Given the etymology of the category "effectiveness", it should be interpreted not as the obtained result of activity, but as the degree of conditions created to achieve the stated goal. That is, effectiveness characterizes the relationship between the result (effect) and the conditions created for its receipt. In our opinion, ME means creating the best social and economic conditions of the organization activity in terms of achieving the goals and strategies determined by the enterprise management, within a fixed period, with certain qualitative and quantitative indicators of effectiveness and the lowest resource costs.

Development, implementation and practical application of methods for assessing ME at present is important for the improvement of the financial, economic and social status of any enterprise, especially in terms of economic instability, which is a key characteristic of the emerging economies. Today, a number of models of an enterprise 
performance management are presented in the scientific literature. They differ by the composition principles, scope of coverage, orientation to different groups of users, etc. The most famous models are the Balanced Scorecard by R. Kaplan and D. Norton, Lorenz Meisel model and the Performance Pyramid by C. J. McNair, R. L. Lunch and K. F. Cross [10], 11], [12].

The key idea of the Balanced Scorecard by R. Kaplan and D. Norton (BSC-Kaplan-Norton) is the development of an enterprise-oriented strategy, with further decomposition of goals for each particular unit and performer in form of the so-called Key Performance Indicators. BSC-Kaplan-Norton includes three main elements and the corresponding procedures: the development of a strategic task map; forming up a tactical balanced scorecard; carrying out the planning, information collection, monitoring of actual indicators values and control. The model focuses on the relationships between individual indicators and elements. The main purpose of BSCKaplan-Norton is to balance up the enterprise's activities in time and space. The first component means that the indicators used for control have to meet the tactical objectives, which are developed and based on the strategic goals while the system's current activity is to support the enterprise movement in this direction. The second component requires the indicators to be balanced by departments and fields of activity. The balance is more important characteristic of the system than a set of indicators that is not always acceptable in assessing the manufacturing enterprise activities, particularly the activities of ESE [10].

The Lorenz Meisel model is similar to the previous one in many respects. It reflects the parameters or criteria (blocks) that describe the relationships with customers, internal activity of an enterprise, financial support for management decisions and the prospects for human resource development. Meisel focuses mostly on the parameter of human resource within which innovative activity, personnel education and training, etc. are subject to assessment [11]. However, the environmental factors, which are crucial to assessing the level of the enterprise ME in emerging economies, are not taken into account. For example, environmental contamination causing by and influencing on the activity of Ukrainian ESE will be missed in this model.

Another model is the Performance Pyramid that was developed by C. J. McNair, R. L. Lunch and K. F. Cross. The latter includes 4 levels of the enterprise organizational structure and indicates the two-way communication system necessary for spreading the ideas of corporate strategy at all hierarchy levels. It is required that the goals and indicators are consistent with the enterprise strategy and its activities. In other words, the goals of the enterprise spread from the higher hierarchy levels to the lower ones, at the same time adapting to the characteristics of each level, and the activity assessment indicators are transferred from the bottom up, creating a coherent picture [12]. However, such a hierarchy does not allow taking into account the sectoral specific nature of the enterprises' activity to the full extent, in particular ESE, and the unstable conditions of their activity in emerging economies.

Determination of the differences in approaches to the essence of the ME concept depends on the object of study, factors taken into account, and the level of considering the object of study. The ambiguity of the interpretation of ME definition causes controversy and inconsistency of scientific approaches to the methods of the ME assessment, as well as the development of an algorithm for its conduction. It complicates a practical use of this powerful tool for improving the efficiency and effectiveness of enterprises, especially ESE. The above outlined problems are still unsolved at the theoretical and methodological levels and require further research. It has determined the choice of the theme and the setting of the article objectives.

Specifying the subject of our research and taking into account the previous scientific works, we will consider efficient management of ESE as the efficient usage of a complex of interacted instruments of economic and administrative influence, which provides sufficient quality of electricity supply services, high level of resources use, timely response to ecological challenges, risk minimization, maximization of the usage of existing opportunities, gaining economic benefits from energy supply activities. As shown in the paper [13], there is a rational combination of tools of positive and negative motivation for achieving the greatest economic benefit while increasing the constructive influence of ESE on the environment.

\section{Methods and Methodology}

The development of the methodological approach to assessing the ME of ESE involves the formation of criteria and indicator system that can influence the level of ESE performance. Such criteria are the basis for carrying out the estimation [14]. Getting high estimate of $\mathrm{ME}$ is possible on condition of the construction of a successful system of enterprise management that increases the adaptability of ESE to external determinants and involves the best opportunities generated by internal factors. Depending on the strength of the external and internal environmental factors' impacts, one of them may be dominant and therefore may have the greater influence on an enterprise operating. In this regard, 
ME of ESE will be determined by the influence level of the internal and external environmental factors and the degree of their interaction. Therefore, the initial stage of the approach to assessing ME of ESE is a detailed study of the determinants affecting the level of ME.

The relevant factor analysis should be conducted considering not only an enterprise's macro- and microenvironment (external environment) but also the factors of the very enterprise, which depend on its business processes (internal environment). Regarding assessing the influence of external environmental factors on the ME level of ESE, it is also important to analyse the existing public, economic, technological and innovative issues as well as multifaceted and multi-structural activity of the ESE. Therefore, it is advisable to structure the external environmental determinants using the method T.E.M.P.L.E.S. (Technology, Economy, Market, Politics, Laws, Ecology, and Society) [16]. However, based on [6], [10], the authors have adjusted this method for assessing the ME of ESE and covering a significant amount of the external environmental factors of influence.

An important component of the ME estimation is the analysis of the relationships of an enterprise with consumers and suppliers. The efficiency of the production process and the quality of provided services depend on the level of cooperation with suppliers of resources, spare parts, components, etc. The customer satisfaction with the electricity supply services affects the efficiency of sales management of ESE. Provision of services meeting the consumers' needs, the rapid elimination and prevention of emergency situations, responding to complaints, etc. allow improving basic service quality and creating demand for the additional related ESE products. Factors of an economic entity internal environment influencing $\mathrm{ME}$ are the economic situation, organizational structure of ESE, technical capacity, innovations and destructive impact of the ESE on the environment (Fig. 1).

The diversity and multiplicity of the determinants affecting ME of ESE requires the formation of an integrated indicator at the next stages of the methodological approach. This indicator will allow assessing the degree of goals achievement and ESE adaptation to the impact of external and internal environmental factors.

In our opinion, the system of indicators has to meet the following requirements while forming an integrated estimation indicator: (1) the compliance with the objectives of the ME estimation; (2) the completeness of an enterprise performance reflection. The first requirement ensures finding ways and possibilities for improving the ME of ESE activity, while the second one provides the creation of an adequate set of indicators to carry out the estimation.

Formation of criteria and indicators has to be conducted considering the effects planned to be achieved in management process as well as internal and external determinats. The estimation is proposed to be carried out based on the algorithm presented in Table 1. Formation of the indicators of different levels for estimating the ME of ESE will be conducted within the framework of a certain block system, which covers the assessment of ME by the factors of an enterprise internal $\left(\mathbf{I}_{\mathbf{v}}\right)$ and external micro- and macroenvironment $\left(\mathbf{I}_{\mathbf{z}}\right)$.

ME estimation by determinants of an enterprise internal environment

Internal environmental factors are a set of all internal variables that determine the processes of an enterprise's activity and its potential for productivity growth [14, 15]. Effective use of internal reserves and resources affects the overall performance. In fact, an enterprise's internal environment is the source of accumulation of its financial, technical, human resources and innovative capabilities. Formation of a system of primary and complex indicators for assessing $\mathrm{ME}$ is influenced by the internal environment factors $\left(I_{v}\right)$ and will be carried out for separate factor directions. Now we will look closely at each of the given directions.

Economic efficiency $\left(I_{v l}\right)$ shows the rationality of an enterprise activity, i.e. getting the maximum possible economic effect of activity with minimal resource costs. The economic effect is reflected by various cost indicators that demonstrate the intermediate and total results of ESE work and influence the financial stability, services profitability and financial management of the enterprises.

The organizational and structural efficiency $\left(I_{v 2}\right)$ refers to the formation of an efficient development strategy, stabilization of an enterprise activity, human resources support, an increase in the velocity of decision-making, etc. The organizational and structural effectiveness includes management process effectiveness, management organizational structure effectiveness and human resource ME. The second direction, which is the organizational structure efficiency, is determined by the degree of its facilitating the achievement of the target-oriented directions of an enterprise development due to its potential. In addition, the organizational structure efficiency shows directions' implementation in the most economical way by the functional subsystems interactions. The organizational structure functioning efficiency depends on the degree of orderliness and its elements interaction for receiving an integrated overall effect in the future. 


\begin{tabular}{|c|c|}
\hline \multicolumn{2}{|l|}{ Complex and primary indicators $\mathrm{ft}$} \\
\hline internal environmental determinants $\left(I_{v}\right)$ & \multirow{3}{*}{$\begin{array}{l}\text { external environmental determinants }\left(I_{z}\right) \\
\begin{array}{l}\text { External environment estimation by indirect influence, } \\
\text { (adaptability, minimizing threats, use of opportunities) }\end{array}\end{array}$} \\
\hline Economic efficiency, Iv $\mathbf{v}_{1}$ & \\
\hline - Efficiency of financial stability management, $\mathbf{A}$ & \\
\hline - Solvency managerial effectiveness, $\mathbf{B}$ & \multirow{4}{*}{$\begin{array}{l}\text { - Public influence, A (compliance of a company activity with } \\
\text { established legislation requirements; timely consideration of legislative } \\
\text { changes in the company activity; the possibility of participation in the } \\
\text { international grants or programmes }\end{array}$} \\
\hline - Efficiency of cash flow management, $\mathbf{C}$ & \\
\hline Organizational and structural efficiency, $I_{2}$ & \\
\hline \multirow{2}{*}{$\begin{array}{l}\text { - Management process effectiveness, D (qualitative and quantitative } \\
\text { composition of management personnel; movement of management } \\
\text { personnel; remuneration and motivation system; the level of maintenance } \\
\text { costs of management personnel) }\end{array}$} & \\
\hline & $\begin{array}{l}\text { international grants or programmes } \\
\text { - Social influence, B (social security of the population; education level } \\
\text { of the population; age and gender structure of the population) }\end{array}$ \\
\hline $\begin{array}{l}\text { - Efficiency of a company management structure, } \mathbf{E} \text { (building the structure } \\
\text { of company management; level of centralization and decentralization of a } \\
\text { company management; the formalization level of company management; } \\
\text { company management information and communication system) }\end{array}$ & $\begin{array}{l}\text { - Scientific and technical influence, } \mathbf{C} \text { (sufficient scientific potential for } \\
\text { the industry functioning; available innovative developments; sufficient } \\
\text { production volumes or import of the equipment and its components) }\end{array}$ \\
\hline \multirow{2}{*}{$\begin{array}{l}\text { - Efficiency of human resource management, } \mathbf{F} \text { (qualitative and quantitative } \\
\text { composition of company personnel; personnel movement; working time use; } \\
\text { remuneration and motivation system) }\end{array}$} & $\begin{array}{l}\text { - Geographical influence, D (transport connection; company provision } \\
\text { with resources necessary for its activity) }\end{array}$ \\
\hline & \multirow{3}{*}{$\begin{array}{l}\text { - Economic influence, } \mathbf{E} \text { (the availability of budget financing for ESE; } \\
\text { the level of fluctuations in the hryvnia exchange rate against foreign } \\
\text { currencies; inflation rate; prices on energy resources) }\end{array}$} \\
\hline Management efficiency by types of activity, $\mathrm{Iv}_{3}$ & \\
\hline $\begin{array}{l}\text { - Efficiency of production activity, G (use of work equipment; use of } \\
\text { materials and raw materials, other production resources; etc.) }\end{array}$ & \\
\hline $\begin{array}{l}\text { - Efficiency of marketing activity, } \mathbf{H} \text { (competitiveness of electricity supply } \\
\text { services; results of the electricity supply services provision (revenue, profit, } \\
\text { etc.); quality level of the provided services) }\end{array}$ & \multirow[t]{2}{*}{$\begin{array}{l}\text { - Environmental influence, } \mathbf{F} \text { (environmental pollution extent and ESE } \\
\text { contribution to these processes; public regulation of the natural } \\
\text { resources rational use and environmental safety of production; } \\
\text { environmental awareness level of the ESE employees) }\end{array}$} \\
\hline - Efficiency of investment activity, $\mathbf{J}$ (investments in fixed assets and & \\
\hline $\begin{array}{l}\text { running capital, scientific and technical products, intellectual assets and } \\
\text { property rights of the company) }\end{array}$ & \multirow[t]{2}{*}{$\begin{array}{l}\text { External environment estimation by the direct influence, Iz2 (level } \\
\text { of balance of consumers' and suppliers' interests) }\end{array}$} \\
\hline Efficiency of innovation component management, $I_{\mathbf{4}}$ & \\
\hline - Innovation effectiveness of production management, $\mathbf{K}$ & \multirow{3}{*}{$\begin{array}{l}\text { - Balance of interests "enterprise - consumer", } \mathbf{G} \text { (presence of regular } \\
\text { consumers; number of consumers; consumer loyalty) }\end{array}$} \\
\hline - Effectiveness of marketing innovations, $\mathbf{L}$ & \\
\hline - Effectiveness of innovation in human resource management, $\mathbf{M}$ & \\
\hline Environmental Performance, $I_{5}$ & \multirow{3}{*}{$\begin{array}{l}\text { - Balance of interests "enterprise-supplier", H (high quality of delivered } \\
\text { products; long-term partnerships with suppliers) }\end{array}$} \\
\hline - Efficiency of environmental compatibility of production, $\mathbf{N}$ & \\
\hline - Efficiency of environmental-oriented management, $\mathbf{P}$ & \\
\hline
\end{tabular}

Figure 1. Set of indicators for evaluating ME of ESE regarding the influence of internal and external environmental determinants (developed by the authors)

Efficiency of the company main activities management $\left(I_{v 3}\right)$, including ESE, has generally accepted classification, i.e. production (operational), marketing and investment activities. In particular, the production activity is a set of purposeful actions of the workers who use labour tools to convert raw materials to the final product (electricity). Management of such enterprise activities is a part of the overall enterprise management system. Estimating the effectiveness of production activity enables its further adjustment and forecasting.

A system approach to the development of a competitive environment in the electric power sector and the analysis of factors influencing ME of ESE have proved the importance considering the efficiency indicators of marketing activity management. However, the marketing activity at ESE in Ukraine is neglected due to enterprises' monopoly position at the market. The criterion for the efficient marketing activities of the ESE is the level of protection from competition and the creation of competitive advantages of the enterprise. This aspect of efficiency becomes increasingly important today owing to the liberalization processes of the Ukrainian electricity market.

Investment activity reflects a set of measures on making investment in every form aimed at the profit earning or social effect achievement. The efficiency of investment activity management refers to providing the best ways for introducing the investment strategy of an enterprise at its early development stages. The ultimate result of the efficient management of an enterprise investment activity is the maximization of its market value in the current and future periods, which is achieved by improving the organizational and information security, planning and monitoring investment projects. For Ukrainian ESE, reaching a high level of investment attractiveness is still a problem. Therefore, their current investment is carried out by means of increasing the price of electricity supply services to include an investment component.

The ME of innovation component $\left(I_{v 4}\right)$ is determined by the enterprise innovation use and its influence on economic indicators, in particular, on the increment of profit volume achieved due to the cost reduction, sales rise, products quality improvement, reduction of negative environmental impact. Estimating the ME of the innovation activity, one should consider innovations in production, human resource and marketing. Implementation of innovative methods increases the productivity of management process. The introduction of the latest technologies allows rising the efficiency of equipment use, reducing the material intensity of products and environmental damage, thereby increasing the level of profitability, competitiveness, the environmental friendliness of an enterprise.

Environmental performance of the ESE management system $\left(I_{v 5}\right)$ has two aspects. Firstly, it is the ecological intensity of the electricity generation (transportation, consumption), and secondly, the focus of the enterprise management on reduction of the negative impact on the environment. 
Table 1. Estimation stages of ME of ESE (developed by the authors on the basis of [6], [9], [14], [17])

\begin{tabular}{|c|c|}
\hline & Formula \\
\hline $\begin{array}{l}\text { 1. Calculation } \\
\text { of primary } \\
\text { indicators }\end{array}$ & $\begin{array}{l}a_{n}, b_{n}, c_{n}, d_{n}, e_{n}, f_{n}, g_{n}, h_{n}, j_{n}, k_{n}, l_{n}, m_{n}, \\
s_{n}, p_{n} \text { (see Fig. 1) }\end{array}$ \\
\hline $\begin{array}{l}\text { 2. Calculation } \\
\text { of local } \\
\text { indicators by } \\
\text { the determined } \\
\text { directions of } \\
\text { estimation }\left(L_{i}\right)\end{array}$ & $\begin{array}{l}\qquad L_{i}=\frac{1}{n} \sum_{i=1}^{n} l_{i} \\
\text { where } L_{i}-\text { is the local indicator of the } \\
i \text {-th direction of estimation; } l_{i}-\text { are } \\
\text { primary indicators, } \mathrm{n}-\text { number of } \\
\text { directions }\end{array}$ \\
\hline $\begin{array}{l}\text { 3.1. Calculation } \\
\text { of the complex } \\
\text { indicator of the } \\
\text { enterprise } \mathrm{ME} \\
\text { influenced by } \\
\text { the internal } \\
\text { environmental } \\
\text { determinants } \\
\text { considering the } \\
\text { indicators } \\
\text { weight }\left(I_{v}\right)\end{array}$ & $\begin{array}{l}\qquad I_{v}=I_{1}^{a 1} \cdot I_{2}^{a 2} \cdot I_{3}^{a 3} \cdot I_{4}^{a 4} \cdot I_{5}^{a 5}, \\
\text { where } I_{1}, \ldots, I_{5}-\text { are group indicators } \\
\text { by structural efficiency directions }(1- \\
\text { economic, } 2-\text { organizational and } \\
\text { structural efficiency, } 3-\text { by types of } \\
\text { activity, } 4-\text { innovative, } 5- \\
\text { environment); } a_{1, \ldots,} a_{5}-\text { are the } \\
\text { weights of the indicators. }\end{array}$ \\
\hline $\begin{array}{l}\text { 3.2. Calculation } \\
\text { of the complex } \\
\text { indicator of the } \\
\text { enterprise } \mathrm{ME} \\
\text { influenced by } \\
\text { the external } \\
\text { environmental } \\
\text { determinants } \\
\text { considering the } \\
\text { indicators } \\
\text { weight }\left(I_{z}\right)\end{array}$ & $\begin{array}{l}\qquad I_{z}=I_{1}^{a 1} \cdot I_{2}^{a 2} \text {, } \\
\text { where } I_{1}, I_{2}-\text { are group indicators of } \\
\text { the level of adaptability, usage of } \\
\text { existing possibilities, reduction of } \\
\text { existing threats and balancing interests } \\
\text { of suppliers and consumers; } a_{1}, a_{2}- \\
\text { are the weights of the indicators. }\end{array}$ \\
\hline $\begin{array}{l}\text { 4. Calculation } \\
\text { of the } \\
\text { integrated } \\
\text { indicator of the } \\
\text { ME of ESE }\left(I_{e}\right)\end{array}$ & $\begin{array}{l}I_{e}=\sqrt{I_{v} \cdot I_{z}} \text {; } \\
\text { where } I_{v}-\text { is the complex indicator of } \\
\text { the enterprise ME influenced by the } \\
\text { internal environmental factors; } \\
I_{z}-\text { is the complex indicator of the } \\
\text { enterprise ME influenced by the } \\
\text { external environmental factors. }\end{array}$ \\
\hline
\end{tabular}

In general, improving the $\mathrm{ME}$ based on the indicators of internal environmental factors influence is an essential tool for ESE stabilization and development. Each management decision should match a certain value of the efficiency criterion. At the same time, the main task of management is to find a solution for which the corresponding indicator has an optimal value. The results obtained while assessing the ME of ESE based on the developed scorecard, allows decision-making aimed at improving efficiency and solving topical issues regarding the internal development of ESE.

$M E$ estimation by determinants of an enterprise external micro- and macro-environment

The primary and complex indicators for estimating the ME of ESE due to the influence of external macro- and microenvironmental factors are presented in Fig. 1. The determinants of the micro-environment are of direct influence, while the macro-environment has an indirect effect on the ME of ESE. Therefore, an enterprise should adapt to the influence of the indirect factors as much as possible through interaction with them. Instead, the determinants of direct impact usually provide more opportunities for an economic entity to adopt. In particular, these factors are relationships with suppliers and consumers, which can be formed and regulated by the enterprise management. The estimation criterion is the level of interests' balance achieved among enterprises, suppliers, and consumers.

The estimation indicators of the determinants of indirect environmental influence should include adaptability, use of the created opportunities and minimization of existing threats that have arisen due to the influence of external environmental factors. For example, the factor of indirect public influence determines not only the level of ESE adaptation to changes but also the use of state-created opportunities for the enterprise. The latter include advanced training programmes in the field of public regulation of the enterprise human resource, the enterprise's employees acquaintance with legislation changes, ESE opportunities to participate in public policy implementation in the energy sector, etc. The international vector of public development, namely the availability of foreign grants, programmes of support and economic assistance from international organizations or other states and the possibility of attracting them by ESE is an essential direction for increasing the ME of economic entities.

The influence of social determinants on the ME of ESE is considered using the following indicators: the level of social security of the population; the possibility for ESE employees to obtain higher education in the relevant field; age and gender structure of the population in the region as a characteristic of the labour force sufficiency for ESE activities, etc. The mentioned indicators create both discouraging and motivating impact on results obtained by ESE.

Within the scientific and technical direction of forming the indicators of external environment indirect influence, it is necessary to reveal additional opportunities, which make available to use the ESE scientific potential for industry functioning, namely carrying out R\&D relevant to the industry, conducting innovative product developments in the energy sector, human resource management and marketing, etc.

As the ME determinant, the geographical location of ESE involves the use of opportunities created by the transport system, available primary energy, and other natural resources, etc. 
The influence of the external economic factors can be assessed by the possibilities of attracting additional financial resources to ESE: both budget financing and loans from private banking institutions. Besides, the inflation rate dynamics and fluctuations in the hryvnia exchange rate require the ESE management to adapt to changes quickly and minimize the negative effects of their impact.

Efficient management of ESE should comply with the criterion of human life safety and a certain level of environmental quality. Therefore, the primary influence of external environment on the ME caused by the ecological factor includes, first of all, the level of environmentally destructive load as a result of ESE activity and leads to the increase in the population morbidity in the region, the need in additional air and water purification, and waste disposal.

In addition, ME is affected by the ESE striving to bring their environmentally destructive load in accordance with the established environmental standards. Herewith, the indicators for estimating the external environmental factor influence are the level of environmental pollution, the compliance with environmental legislation, the rational use of natural resources, and public control over the environmental safety of electricity generation and distribution.

To calculate the integrated indicator of the ESE ME considering the influence of the determinants' combination, we used the multiplier formula. The integral indicator shows the level of ESE ME and was counted using the geometric mean since it allows the analysis of the dependence between the integral ME level and the combination of external and internal environmental factors.

Thus, using the integrated methodological approach, we have formed a system of taxonomic indicators to estimate the level of ESE ME caused by the impact of various factors. One of the approach advantages is the determination of indicators weight for ranking its influence on ME. It is proposed to carry out using the expert assessment method. When forming an expert group, it is necessary to attract specialists who are knowledgeable about the researched problems, have a high level of professionalism and practical experience. Expert assessment has been carried out by the Delphi method. The statistical significance of the coefficient of concordance was verified by Pearson's criterion. The calculations were made using Mathcad Prime 3.0 software. The analysis of the expert survey results, and determination of the indicators weight were carried out using the Expert Choice 11.5 software package.
The Harrington scale was used to interpret ME level estimates. According to the scale, an indicator in the range of 0-20 corresponds to a critical level, 21-38 - unsatisfactory, 39-50 - low, 51-64 - average, 65-79 - sufficient and 80-100 - to a high level of ESE ME [17].

\section{Results and Discussion}

The developed methodological approach was verified on the example of 4 ESE from the northern and central regions of Ukraine, i.e.: Zhytomyroblenergo JSC, Chernihivoblenergo JSC, Kyivoblenergo CJSC and Sumyoblenergo OJSC [18], [19], [20], [21]. The enterprises' statistical reports for 2015-2018 years were used in this study. The required number of experts to determine the weights of ME indicators was calculated according to the above methodology based on the theory of sample observation. Assuming that a confidence level of P equals 0.954 and the sample size is large enough, we fixed the Student's t-test, which equaled $t$ $=1.964$. With a reliability of $95 \%$ and a maximum permissible relative error of 0.05 , the number of experts involved to estimate the indicator weights was 15 people.

Among the special requirements to the experts were higher specialized education and work experience in the industry for more than ten years. Therefore, the expert group consisted of professionals from Sumyoblenergo OJSC and Zhytomyroblenergo JSC. The indicator of compliance with the qualitative characteristics of the expert group was 0.8 . It presents the high-quality of the selected expert team.

A graphical representation of the calculation results on the example of 2018 was carried out using the cyclogram method [23] (Fig. 2-3). According to this method, the maximum value of a local indicator is taken as 1 ; the rest of the actual indicators are calculated in proportion to the size of the maximum value.

As follows from the calculations, in 2018, the considered ESE had the worst values of local indicators in the field of investment activity efficiency, regarding the influence of the internal environmental factors. Chernihivoblenergo JSC with the indicator equals 0.2 was the outsider, a Zhytomyroblenergo JSC had a slightly better result (0.26). Sumyoblenergo OJSC (0.29) and Kyivoblenergo CJSC (0.4) had low levels of investment ME too. In addition, the innovative and environmental activities of the enterprises should be considered ineffective as well, especially in terms of the environmental performance of production (see Fig. 2). 

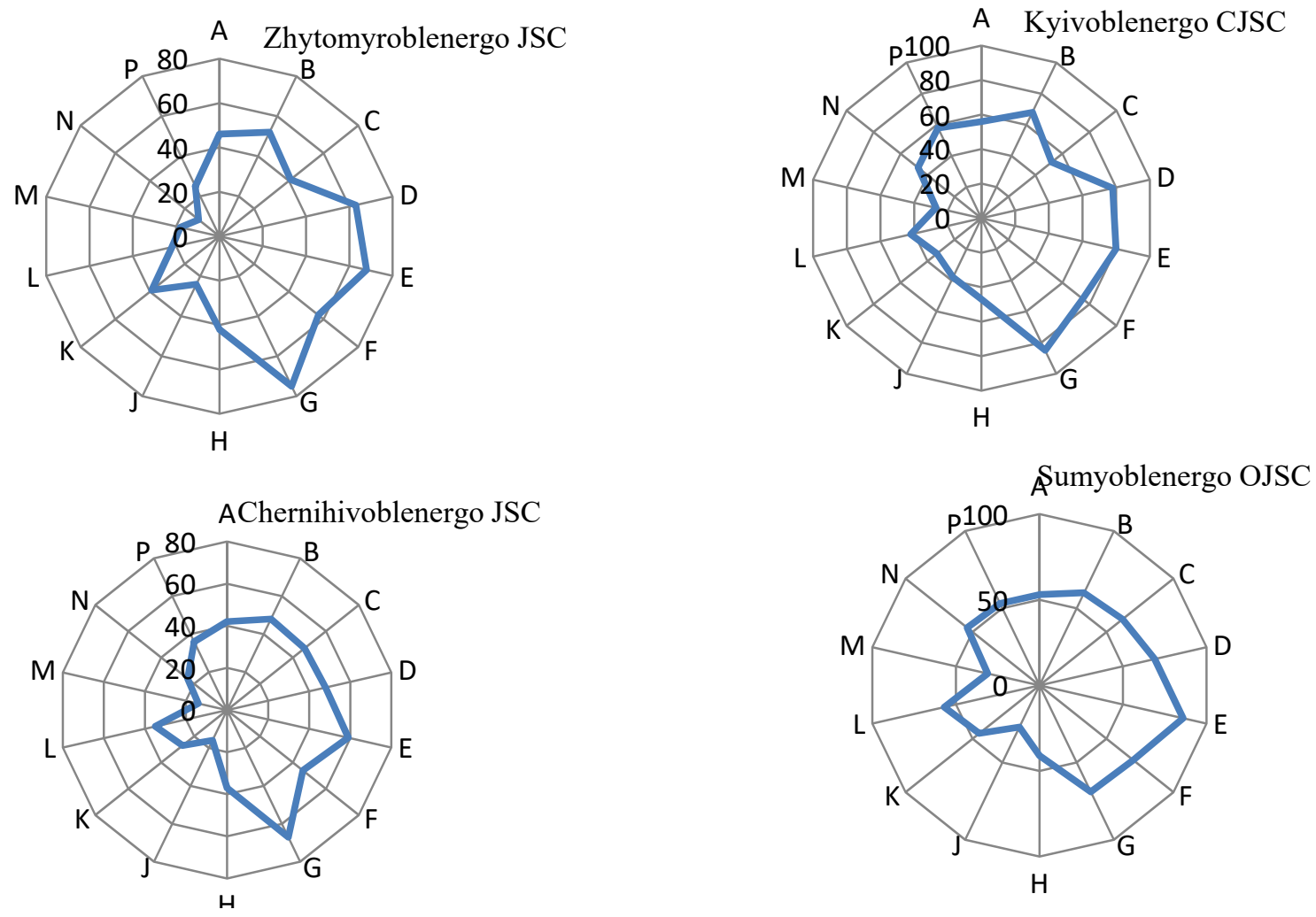

Figure 2. Graphical presentation of the calculation results for local indicators by the directions of estimation of the internal environment influence on the ME of ESE from the northern and central regions of Ukraine, 2018
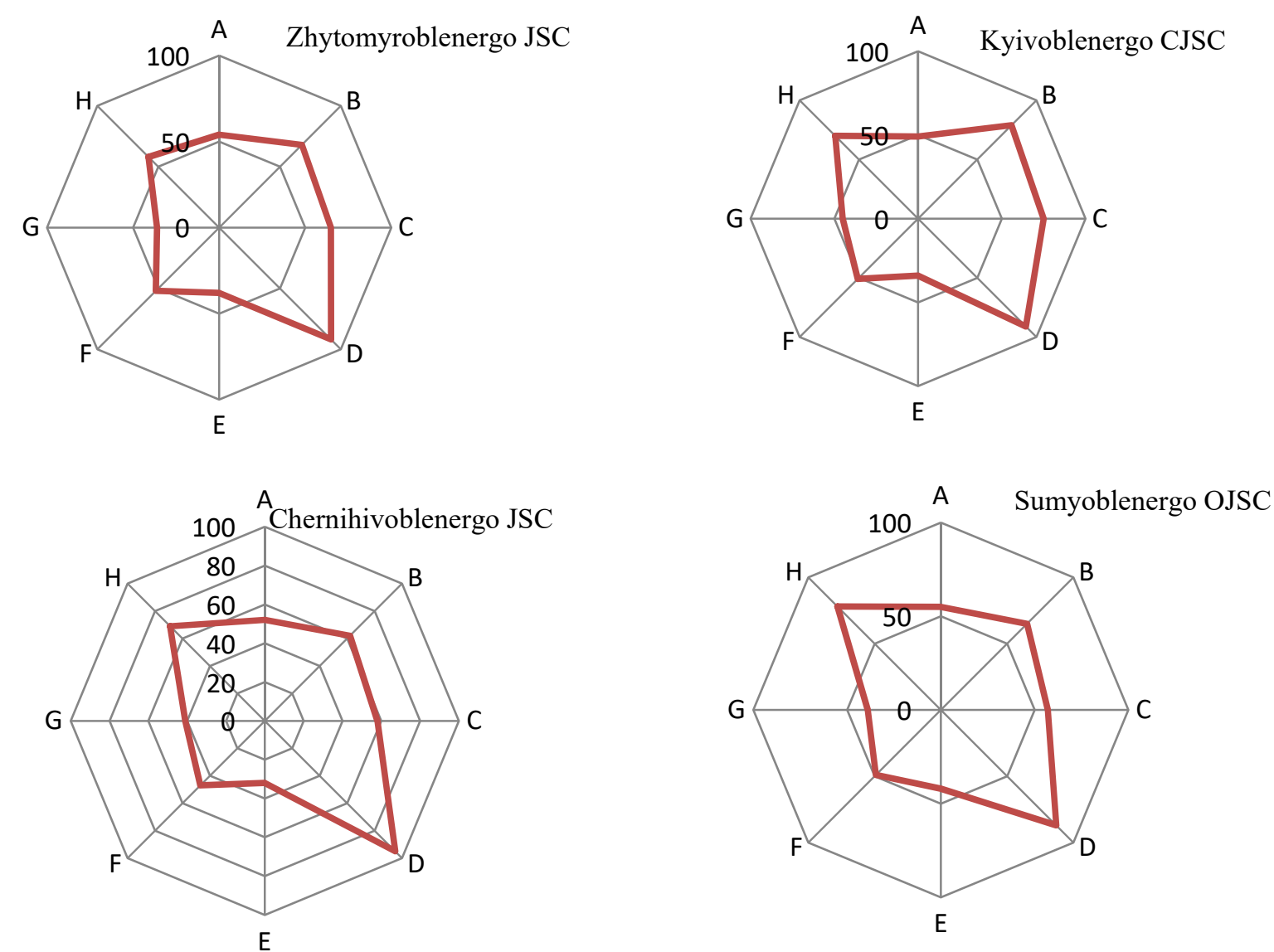

Figure 3. Graphical presentation of the calculation results for local indicators by the directions of estimation of external environment influence on the ME of ESE from the northern and central regions of Ukraine, 2018 
Regarding the influence of external environmental factors, the enterprises have the lowest level of balance of interests "enterprise-consumer". Herewith, the indicator of Zhytomyroblenergo JSC is 0.32, Chernihivoblenergo JSC and Sumyoblenergo OJSC are 0.38 each and Kyivoblenergo CJSC is 0.45 . The low degree of adaptation to the economic determinant influence is proved by its low values for enterprises: 0.32 for Chernihivoblenergo JSC, 0.35 for Kyivoblenergo CJSC, and 0.4 for Zhytomyroblenergo JSC and Sumyoblenergo PJSC. However, the considered ESE adapted to the geographical factor influence and successfully use the existing transport connections. Thus, the calculated data on the influence of this factor for enterprises are: Kyivoblenergo CJSC is 0.91, Chernihivoblenergo JSC is 0.9 , Zhytomyroblenergo JSC is 0.87 , and Sumyoblenergo OJSC is 0.8 (see Fig. 3).

Calculated considering the weights, complex indicators, which reflect the internal and external environment determinants influence, are given in Table 2 .

Table 2. Complex indicators that reflect the influence of internal and external environmental factors on the level of ESE ME (authors' development)

\begin{tabular}{|c|l|l|}
\hline \multirow{1}{*}{ Enterprise } & $\begin{array}{l}\text { Complex } \\
\text { indicator of the } \\
\text { enterprise ME } \\
\text { that reflects the } \\
\text { influence of the } \\
\text { internal } \\
\text { environment } \\
\text { factors and } \\
\text { considers the } \\
\text { weighting of } \\
\text { indicators }\left(I_{v}\right), \\
\text { value/level }\end{array}$ & $\begin{array}{l}\text { Complex } \\
\text { indicator of } \\
\text { the enterprise } \\
\text { ME that } \\
\text { reflects the } \\
\text { influence of } \\
\text { the external } \\
\text { environment } \\
\text { factors and } \\
\text { considers the } \\
\text { weighting of } \\
\text { indicators }\left(I_{z}\right), \\
\text { value/level }\end{array}$ \\
\hline \multirow{2}{*}{ Zhytomyroblenergo } & average & 38,2 \\
\cline { 2 - 3 } Chernihivoblenergo & unsatisfactory \\
\cline { 2 - 3 } & average & 40,22 \\
\hline \multirow{2}{*}{ Kyivoblenergo } & av,96 & low \\
\cline { 2 - 3 } & average & average \\
\hline Sumyoblenergo & 56,32 & 57,23 \\
\cline { 2 - 3 } & average & average \\
\hline
\end{tabular}

The given calculation analysis of local and complex indicators allows estimating the integral level of economic entities ME influenced by all the factors considered. The integral indicator provides the basis for decision-making concerning the improvement of the efficiency of ESE activities, allows analysis of the ME changes over time, identification of both the negative trends of the determinants' influence on the overall level of ME and unused opportunities to improve the ESE performance.

In general, the obtained integrated results show a low level of ME of the considered ESE in 2015-2018 (see Fig. 4). Zhytomyroblenergo JSC has the worst $\mathrm{ME}$ indicator that can be explained by the low level of its external and internal effectiveness. The enterprise's ME was 0.2 in 2015, which is the lowest among all the analyzed ESE in 2015-2018. Kyivoblenergo CJSC has the best ME indicators in 2015-2018 and keeps the highest position regarding internal effectiveness. Inspite of the average indicator of the internal efficiency, Chernihivoblenergo JSC has a low level of adaptability to the influence of external environmental factors, which declines the overall ME effectiveness. Sumyoblenergo OJSC has a negative tendency to ME decrease: in 2015-2018, the integrated ME indicator descended from 0.36 to 0.32 .

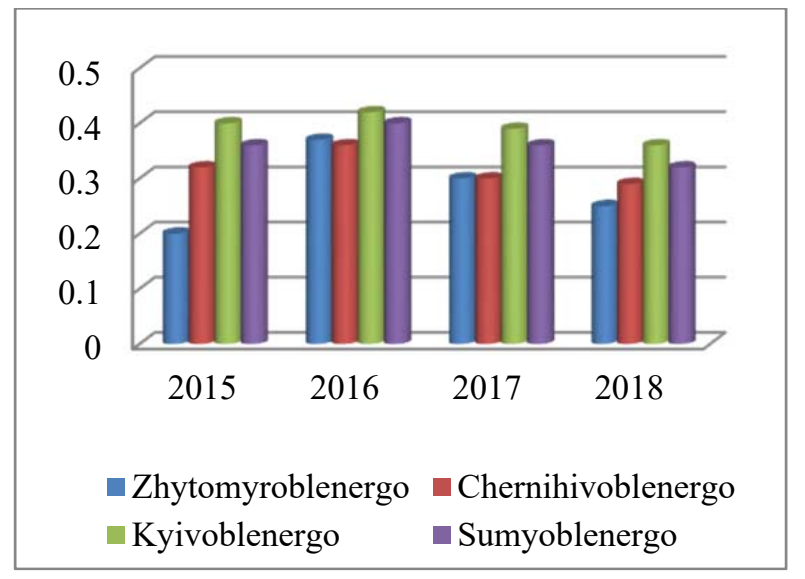

Figure 4. Integral indicator of $M E\left(I_{e}\right)$ of ESE from the northern and central regions of Ukraine, 2015-2018

The obtained results show the low ME of ESE since the highest values of indicators for all enterprises during the study period do not exceed the threshold of 0.42 . This is because today the Ukrainian ESE have accumulated several problems that need urgent solution. The latter include:

- significant obsolescence and physical deterioration of ESE fixed assets (up to 70\%) [7]. Most of the enterprises work with generation facilities whose production resourse was run out 10-15 years ago. It considerably reduces the quality of energy services and declines the overall performance of ESE. The situation is typical for many companies in the sector, considering the poor investment policy in the field;

- debt of the population for the electricity consumed. Despite a rather high payment rate for energy consumption, electricity debts tend to increase. According to the data of the studied ESE, the level of payment for provided energy 
services decreased in 2015-2018 [18], [19], [20], [21] that negatively affected the fulfilment of the ESE financial obligations. On the one hand, electricity prices are constantly growing, but on the other hand, low real income of the population and business does not stimulate timely debt payments for energy consumed;

- the lack of motivation for productive work. Poor indicators of occupational stability, advanced training of production staff and administration were detected among all ESE in the northern and central regions of Ukraine, which decline the ESE performance. The reason for this is the relatively low wages of employees which do not correspond to the level of difficulty and responsibility of the work performed;

- the insufficient number of innovations introduced in electricity generation, marketing and management activities that has a negative effect on profit increase and impedes the development of ESE. One of the reasons for slowing down innovation in the sector is the unsatisfactory investment policy;

- low level of connection to the unified electric grid for power plants that generate electricity from renewable energy resources. It is caused by the slow development of renewable energy in Ukraine [22]. As of the end of 2018, the share of green electricity in the total energy balance of Ukraine amounted to only $1.9 \%$ [23]. Consequently, current electricity generation in Ukraine is still based on fossil fuel resources.

As already mentioned, most of these problems are caused by the unsatisfactory investment policy in the energy sector. Other reasons include the monopoly position of ESE on the market and the inefficiency of the industry public regulation, which does not contribute to the stable development of ESE.

\section{Conclusion}

The problems of ensuring efficient management of energy enterprises, as well as economic entities in other fields of activities, are relevant for any national economy. These issues are getting critically important for the energy, housing and utilities sectors in emerging economies, which suffer from many structural and system problems. In this regard, the methodological approach proposed in the article contributes to the adequate and complex assessment of ME of ESE, considering the impact of the external and internal environmental determinants. The developed integrated indicator creates opportunities for a comprehensive estimation of ESE ME and operational and strategic decision-making on the reformation of ESE activities.

The outcomes of testing the methodological approach that was carried out on the example of the ESE from the northern and central regions of Ukraine, have showed low ME of ESE and made it possible to identify specific issues requiring pressing solutions for each of the considered ESE.

Based on the research results, the main recommendations for the improvement of $\mathrm{ME}$ of the studied ESE are as follows: firstly, to ensure the attraction of significant investments for updating ESE fixed assets on the innovative basis and renewable energy sources involvement; secondly, to liberalize the domestic electricity market through creating conditions to provide competitive energy supply services and eliminate the monopoly influence; thirdly, to introduce an effective motivational mechanism for stimulating the development of renewable energy; fourthly, to strengthen the responsibility of consumers for the timely payments for electricity consumed to ensure the stable functioning of ESE, etc.

Overall, the introduction of an integrated approach to estimating ME allows an enterprise to increase its $\mathrm{ME}$, improve profitability and monitor the efficiency of a company's business processes. The approach can be used for any energy supply enterprise in terms of emerging economy. The further research in this field requires the study of practical aspects that will allow the implementation of estimation results in enterprise management processes to increase the effectiveness of its activity.

\section{Acknowledgements}

The publication contains the results of research carried out within the framework research projects supported by the National Research Foundation of Ukraine "Formation of economic mechanisms for sustainable development of renewable energy in the conditions of global and local threats to energy security of Ukraine" (No. 2020.01/0135), and "Stochastic modelling of road map for harmonizing national and European standards for energy market regulation in the transition to a circular and carbon-free economy" (No. 2020.02/0231). 


\section{References}

[1]. Sineviciene, L., Sotnyk, I., Kubatko, O., \& Lakstutiene, A. (2017, May). What makes countries to be energy efficient: case of Lithuania and Ukraine?. In Economic Science for Rural Development Conference Proceedings (No. 45).

[2]. Energy Strategy of Ukraine till 2035 (2017). Retrieved from:

https://zakon.rada.gov.ua/laws/show/605-2017$\%$ D1\%80. [in Ukrainian] [accessed: 10 June 2020].

[3]. Kushlik O. (2017). Strategic management in ensuring the efficient operation of ESE. Economic Herald of Zaporizhzhya State Engineering Academy, vol. 1-1, 108-112. [in Ukrainian]

[4]. Pererva, P., Omelyanenko T. (2014). Formation of the Value of Relations between Power Supply Enterprises and Electricity Consumers. Marketing and Management of Innovations, 1, 152-160.

Retrieved from: http://nbuv.gov.ua/UJRN/Mimi 2014_1 17 [in Ukrainian]. [accessed: 15 June 2020].

[5]. Kvyatkovskaya, L. Vorobyova, L. (2013) "Integrated approach to the assessment of the efficiency of enterprise management", Visnyk Natsionalnoho tekhnichnoho universytetu "KhPI", 50 (1023), (pp. 6775). Kharkiv, Ukraine. Retrieved from: http://nbuv.gov.ua/UJRN/vcpiay $2013 \quad 50 \quad 15$. [in Ukrainian]. [accessed: 18 June 2020].

[6]. Makarenko, M. (2005). Formation of the mechanism for managing the effective functioning of the enterprise. Actual problems of the economy, 1, 126135.

[7]. Drucker, P. F. (1994). Menedżer skuteczny, wyd. Akademii Ekonomicznej w Krakowie, Kraków, 39-40.

[8]. Cheymetova, V. A., \& Scherbakov, V. V. (2017). Methodological approaches to managerial efficiency evaluation of organization. Espacios, 38(48), 8-8.

[9]. Pawłowski, M., Piątkowski, Z., \& Żebrowski, W. (2009). Management efficiency.foundations of management, 1(1), 95-110.

[10]. Kaplan, R., \& Norton, D. (1996). The Balanced ScoreCard: translating strategy into action, Boston Mass. Harvard Business Review Press.

[11]. Maisel, L. S. (1992). Performance measurement: the balanced scorecard approach. Journal of cost management, 6(2), 47-52.

[12]. McNair, C. J., Lynch, R. L., \& Cross, K. F. (1990). Do financial and nonfinancial performance measures have to agree?. Strategic Finance, 72(5), 28.
[13]. Bednarski, A. (2001) Essay on the theory of organization and management. Torun: TNOIK.

[14]. Khrystenko, L. (2009). Influence of internal environmental factors on efficiency enterprise management. Visnyk of Khmelnytskyi National University, Issue 4/2, $141-144$.

[15]. Prokopenko, O. V., Shkola, V. Y., Domashenko, M. D., \& Prokopenko, M. O. (2015). Conceptual grounds to form motivational constituent of the international ecological policy. Marketing and Management of Innovations, (4), 245-259.

[16]. Worrell, E., Laitner, J. A., Ruth, M., \& Finman, H. (2003). Productivity benefits of industrial energy efficiency measures. Energy, 28(11), 1081-1098.

[17]. Akhaev, A. (2013). An algorithm for evaluating the functional content of software products. Dopovidi TUSURa, 2(28), 169-174.

[18]. Reports on the result of activities JSC "Zhytomyroblenergo". (2018).

https://www.ztoe.com.ua/documents.php [in Ukrainian] [accessed: 10 August 2020].

[19]. Report on the result of activities of PJSC "Chernihivoblenergo". (2018). Retrieved from: https://chernihivoblenergo.com.ua/company/reporting information. [in Ukrainian] [accessed: 10 August 2020].

[20]. Report on the result of activities DTEK "Kyivoblenergo". (2018). Retrieved from: https://www.dtekkrem.com.ua/ua/file/DFEuLrCDUoNoo?inline $=1$. [in Ukrainian] [accessed: 10 August 2020].

[21]. Report on the result of activities JSC "Sumyoblenergo" (2018). Retrieved from: https://www.soe.com.ua/aktsioneram/osnovnividomosti/zvitnist. [in Ukrainian] [accessed: 15 August 2020].

[22]. Kurbatova, T., \& Skibina, T. (2019, September). Renewable Energy Policy in Ukraine's Household Sector: Measures, Outcomes and Challenges. In 2019 IEEE International Conference on Modern Electrical and Energy Systems (MEES) (pp. 234-237). IEEE. https://doi.org/10.1109/MEES.2019.8896399.

[23]. National Energy and Utilities Regulatory Commission of Ukraine (2019a). Report on the results of National Energy and Utilities Regulatory Commission's activity in 2018: decree No. 440, (2018).

Retrieved from: http://www.nerc.gov.ua/data/filearch/Catalog3/Richny i_zvit_NKREKP_2018.pdf [in Ukrainian] [accessed: 15 August 2020]. 